\title{
プラント建設とコストに関する 実態調查
}

このたび化学工学誌が “ブロシェクトエンジニヤンンク”特集号を企画するに当って, 化学工場の建設 における組樴，建設至目の割合、機器およびニーティリティのコストなどのわが国における実情についての 料を集め，それをまとめて会員諸氏の参考に供することは，わが国におけるこの種の資料が比較的乏しい ことからきわめて意義のあることであると考え，各方面にフンヶートをお原いし，その回答をまとめたのが この調査報告である。

こ協力下さった各社の名前を列記することは問題の性兵上差し控えさせていたたくが，贵重な登料をこ提 供下さったこ協力各社に対しては深甚の謝意を表する次第である。

いたたいた回答を䡖理するについては，多少の条件の美異や個々の場合の特秼事情などにはあまりとらわ れナ゙，一括して表示したために，この調查報告の結果を利用される場合にはその点十分吟味されることをお 頧いする。

Iフプラントの設計，建設の組織
A. プラントの設計・建設を行な 5 比率
B. フラントの設計・建 設を行ならときの職種・人員

II.プラント建設費内訳比率
A. 主として饬体を报ら装置
B. 主として固体を报ら装盖
C. 流体および固体を报 5 紫置

III. 各種化学機器の価格

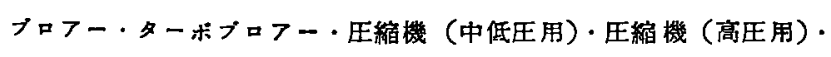
遠心ポンフ・遠心ポンフ (タービン)・真空ポンフ (往復) ·真空ボン

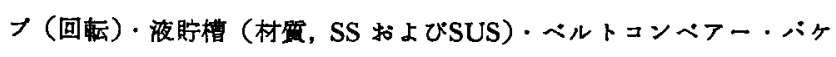
ットコンベー・スクリューコンベフー・檔拌機 (フロヘラ型)・ーダー・シックナー(ローヘッドタイブ)・遠心分離機 (遠心脱水型).

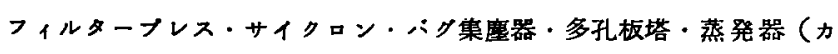
ランドリア型)・熱交換器 (管板直管式, 村筫 SS) 繁交換器（管板直 管式, 村犋 SS, 同一メーカのデータKよる)・熟交換器（管板直管式, 材筫 SUS) · 熟交換器（管板直管式，材害 SS, 同一ニーザのデータに よる)・泡塔（材質 SS 扎よび SUS）

IV. ニーティリティ関係設備の建設費とコスト

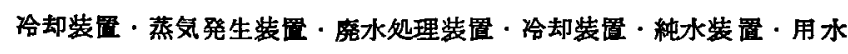
污過装置・発震装置 


\section{I.プラントの設計・建設の組}

本フンケート（A）はブラントの設計・建設の業務が自社と他社とがどんな割合で分担され，(B)は技術者の

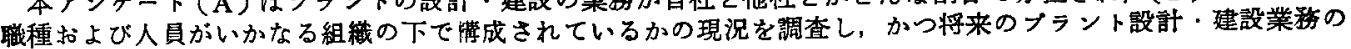
遂行方法に対する資料を提供する目的で行なったすのである。

回答会社数 26 社 (内メーカ 4 社を含む)，ブラント数 38 , 建設年は昭和 30 年 35 年 (昭和 25 年 1 社) である。 また、ブラント数 38 の5ち建設費 1 億以下 $10,1 \sim 5$ 億 $15,5 \sim 10$ 憶 4,10 億以上 6 , 未記入 3 となっている。

I -A プラントの設計・建設を行なう比率注1)

\begin{tabular}{|c|c|c|c|c|c|c|c|c|c|c|c|c|c|c|c|c|c|c|c|c|}
\hline & \multicolumn{10}{|c|}{ 建設曊 1 億以下, 建設年月 昭和 $31 \sim 35$ 年 ${ }^{*}$ 注 2$)$} & \multicolumn{9}{|c|}{ 建 設 费 $1 \sim 5$ 億, } \\
\hline & & $\begin{array}{l}\text { 雄 } \\
\text { 蓕 } \\
\text { 品 }\end{array}$ & 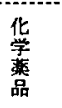 & 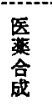 & 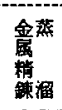 & 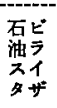 & $\begin{array}{l}\text { 石至 } \\
y \\
1 \\
\text { 油 }\end{array}$ & $\begin{array}{l}\text { 医 } \\
\text { 菂 } \\
\text { 品 }\end{array}$ & $\begin{array}{c}\text { 华真 } \\
\text { 精 } \\
\text { 学溜 }\end{array}$ & $\begin{array}{r}\text { 油分 } \\
\text { 蒸 } \\
\text { 脂滔 }\end{array}$ & $\begin{array}{l}\text { 油 } \\
\text { E } \\
1 \\
\text { 脂 S }\end{array}$ & $\begin{array}{l}\text { 生 } \\
\mathbf{I} \\
\text { ע }\end{array}$ & & & 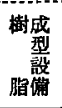 & $\begin{array}{r}\text { 榯穣 } \\
\text { 啳 } \\
\text { 脂板 }\end{array}$ & $\begin{array}{l}\text { 华 } \\
\text { 学 } \\
\text { 品 }\end{array}$ & 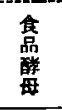 & 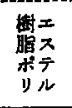 & 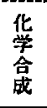 \\
\hline \multirow{3}{*}{ 計 } & (1) 基碮 研究 & 100 & 100 & 100 & 100 & 20 & 30 & 90 & 20 & 30 & 0 & & & & 100 & 100 & 100 & 90 & 90 & 100 \\
\hline & (2) 中間 試 & 100 & 100 & 100 & 100 & - & 100 & 100 & 20 & 10 & 0 & & & & 100 & 100 & 100 & 100 & 100 & 100 \\
\hline & (3) 材 料 試 & 100 & 100 & 100 & 100 & - & - & 100 & 20 & 0 & 0 & & & & 100 & 100 & 60 & 100 & 100 & 90 \\
\hline \multirow{2}{*}{ 画 } & (4) フロンート作成 & 100 & 60 & 100 & 100 & 100 & 100 & 100 & 90 & 100 & 0 & 10 & & 100 & 100 & 100 & 30 & 100 & 100 & 100 \\
\hline & （5）企䔉化計画 & 100 & 100 & 100 & 100 & - & 100 & 100 & 20 & 30 & 0 & 10 & & 100 & 100 & 100 & 100 & 100 & 100 & 100 \\
\hline \multirow{5}{*}{ 設 } & (6) 器 壻 定 & 100 & 100 & 100 & 100 & 100 & 100 & 100 & 70 & 90 & 0 & 10 & & 100 & 100 & 100 & 100 & 100 & 90 & 90 \\
\hline & (7) 器 設 計 & 80 & 20 & 30 & 80 & 50 & 70 & 90 & 90 & 80 & 80 & 5 & & 50 & 50 & 50 & 30 & 80 & 20 & 80 \\
\hline & (8) 铁架槽颜計 & 20 & 20 & 50 & 80 & 30 & 80 & 100 & 95 & 90 & 90 & 2 & & 20 & 20 & 20 & 20 & 100 & 20 & 100 \\
\hline & (9) 配看 設 & 100 & 90 & 100 & 100 & 90 & 100 & 100 & 90 & 90 & 10 & 10 & & 100 & 100 & 100 & 70 & 100 & 100 & 100 \\
\hline & (10) 配 管設 & 100 & 20 & 100 & 100 & 20 & 50 & 100 & 90 & 90 & 5 & 10 & & 100 & 50 & 70 & 30 & 100 & 70 & 100 \\
\hline \multirow{4}{*}{ 計 } & (11) 計 装 設 計 & 100 & 100 & 100 & 80 & 80 & 100 & 100 & 80 & 80 & 0 & 3 & & 30 & 20 & 20 & 40 & 100 & 90 & 80 \\
\hline & (12) 的力 - 照明設尌 & 100 & 50 & 100 & 100 & 30 & 30 & 100 & 50 & 50 & 0 & 10 & & 100 & 50 & 70 & 50 & 100 & 90 & 100 \\
\hline & (13) 祭 設 計 & 100 & 40 & 0 & 100 & 20 & 20 & 90 & 90 & 70 & 90 & 5 & & 50 & 70 & 70 & 40 & 100 & 70 & 100 \\
\hline & (14) 建 屋 設 計 & 10 & 20 & 10 & 0 & 30 & 30 & 80 & 10 & 0 & 90 & 2 & & 20 & 20 & 20 & 20 & 100 & 20 & 100 \\
\hline \multirow{9}{*}{ 建 } & （15）基 磁 工 事 & 0 & 0 & 0 & 0 & 0 & 0 & 0 & 0 & 0 & 95 & ( & & 0 & 0 & 0 & 0 & 0 & 0 & 100 \\
\hline & (16) 建 家 工 李 & 0 & 0 & 0 & 0 & 0 & 0 & 0 & $n$ & 0 & 50 & ( & & 0 & 0 & 0 & 10 & 0 & 0 & 100 \\
\hline & (17) 铁架榡工事 & 30 & 0 & 15 & 0 & 0 & 0 & 0 & 100 & 100 & 90 & ( & & 0 & 0 & 0 & 0 & 0 & 0 & 100 \\
\hline & (18) 据 付 工 事 & 15 & 10 & 50 & 0 & 0 & 0 & 0 & 100 & 100 & 100 & ( & & 0 & 0 & 0 & 10 & 50 & 0 & 95 \\
\hline & (19) 配 管 工 揫 & 20 & 0 & 20 & 0 & 0 & 0 & 0 & 90 & 70 & 80 & ( & & 0 & 0 & 0 & 20 & 20 & 0 & 100 \\
\hline & (20) 保温 - 保冾工事 & 0 & 0 & 0 & 0 & 0 & 0 & 0 & 80 & 0 & 80 & ( & & 0 & 0 & 0 & 0 & 20 & 0 & 100 \\
\hline & (21) 䖝力・照明工事 & 10 & 0 & 15 & 0 & 0 & 0 & 20 & 30 & 20 & 0 & 2 & & 20 & 0 & 0 & 0 & 0 & 0 & 100 \\
\hline & (22) 計 I & 20 & 0 & 15 & 0 & 0 & 0 & 20 & 0 & 0 & 10 & ( & & 0 & 0 & 0 & 0 & 100 & 0 & 100 \\
\hline & (23) 盗 工 桃 & 0 & 0 & 20 & 0 & 0 & 0 & 20 & 0 & 0 & 80 & rat & & 0 & 0 & o & 0 & 30 & 0 & 100 \\
\hline \multicolumn{21}{|c|}{$I-B$} \\
\hline \multirow{4}{*}{ 計 } & 化学 技術者 & 9 & 注 4) & 5 & 4 & & & & 2 & & & r & & & 1 & 2 & 1 & 1 & & 10 \\
\hline & 化 I & 5 & & 1 & 2 & & & & 3 & & & & & & 0 & 0 & 1 & 1 & & 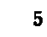 \\
\hline & 铍 造 & & & 5 & 6 & & & & 3 & & & 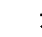 & & & 4 & 1 & 0 & 7 & & 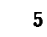 \\
\hline & ブロシェ & & & 1 & 1 & & & & 2 & & & & & & $\mathbf{1}$ & 1 & 1 & 0 & & \\
\hline \multirow[t]{5}{*}{ 画 } & その他技術者 & 1 & & 2 & 10 & & & & 3 & & & & & & 0 & 0 & 2 & 0 & & 8 \\
\hline & 事 确 担 当 & 4 & & 2 & 1 & & & & 3 & & & r & & & 2 & 2 & 1 & 1 & & 3 \\
\hline & 化学 技 㭪 者 & & & 3 & 1 & & & 0 & 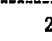 & & 1 & 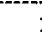 & & & 0 & 2 & 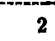 & 1 & 2 & \\
\hline & 化 I " & & & 1 & 1 & & & 2 & 3 & & 1 & 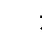 & & & 0 & 0 & 3 & 1 & 1 & 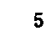 \\
\hline & 造 & & & 3 & 1 & & & 0 & 4 & & 0 & 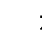 & & & 4 & 2 & 1 & 7 & 2 & 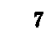 \\
\hline \multirow[t]{3}{*}{ 設 } & 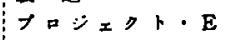 & & & 1 & 1 & & & 0 & 2 & & 0 & & & & 1 & $i$ & 3 & 0 & & \\
\hline & 機诚技行者 & & & 1 & 3 & & & 3 & 6 & & 15 & 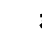 & & & 3 & 3 & 4 & 6 & 1 & 10 \\
\hline & 計 装 & & & 0 & 1 & & & 1 & 2 & & 0 & & & & 0 & 0 & 1 & 2) & & 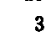 \\
\hline \multirow[t]{7}{*}{ 計 } & 電 & & & 1 & 2 & & & 2 & 1 & & 1 & 2 & & & 1 & 1 & 1 & $\left.{ }_{2}\right\}$ & 1 & \\
\hline & 土 建 & & & 1 & 1 & & & 2 & 1 & & 0 & & & & 1 & 1 & 2 & 2 & 1 & 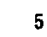 \\
\hline & その他技街者 & & & 0 & 1 & & & 0 & 4 & & 0 & 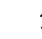 & & & 0 & 0 & 0 & 0 & & \\
\hline & 护提 & & & 1 & 2 & & & 1 & 3 & & 3 & & & & 2 & 2 & 2 & 2 & & \\
\hline & 化工技 旡 者 & 2 & & 1 & 1 & & & 2 & 2 & & 1 & & & & 0 & 0 & 2 & 1 & & \\
\hline & 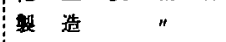 & & & 3 & 1 & & & 0 & 3 & & 0 & (1) & & & 4 & 2 & 2 & 7 & & 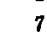 \\
\hline & $\rightarrow a \forall x \Rightarrow+: \mathrm{E}$ & & & 1 & 1 & & & 0 & 1 & & 0 & & & & 1 & 1 & 2 & 0 & & \\
\hline \multirow[t]{2}{*}{ 建 } & 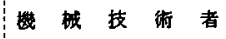 & 4 & & 1 & 6 & & & 3 & 1 & & 13 & & & & 3 & 3 & 1 & 6 & & 10 \\
\hline & 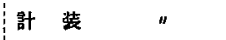 & & & $\mathbf{0}$ & 2 & & & 1 & 1 & & 0 & & & & 0 & 0 & 1 & 2 & & \\
\hline 設 & 電 気 & 5 & & 1 & 3 & & & 2 & & & 0 & & & & 1 & 1 & 1 & 2 & & \\
\hline 双 & 土 建 & $\mathbf{1}$ & & 1 & 1 & & & 2 & & & 0 & & & & 1 & $\mathbf{1}$ & 2 & 2 & & \\
\hline & その他技術者 & 3 & & 0 & 1 & & & 0 & 4 & & 0 & & & & 0 & 0 & 0 & 0 & & \\
\hline & 事 独 & 2 & & 3 & 3 & & & 1 & 1 & & 5 & & & & 2 & 2 & 3 & 2 & & \\
\hline
\end{tabular}


注 :

1. 表は自社で行なら比率の\%である。

2.*日四はメーカの提供以よる。

3: 設計…建設の㬝種・人員化ついて回答をい ただいたのは 26 社の5ち16社のみで, 现 行組機で行な 5 むの 6 社, 臨時編成で行な うすの 10 社である。 臨時稨成の組糡の多くは

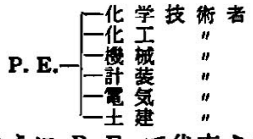

のよ5に P. E. で代表される職制上の责任 者が，建設の規模および業種により関係技 術者を䟽括する組織になっている。

4. 未記入相は資料の提供ないるの。

\begin{tabular}{|c|c|c|c|c|c|c|c|c|c|c|c|c|c|c|c|c|c|c|c|}
\hline \multicolumn{2}{|c|}{ 建設年月 } & \multicolumn{5}{|c|}{ 昭和 $30 \sim 35$ 年 } & \multicolumn{4}{|c|}{ 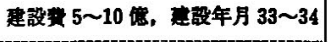 } & \multicolumn{6}{|c|}{ 建設奍 10 倠以上，建設年月 昭和 $29 \sim 35$} & \multicolumn{3}{|c|}{ 建設费不明，25～35 } \\
\hline 醇 & $\begin{array}{l}\text { 华 } \\
\text { 掌 } \\
\text { 嵒 }\end{array}$ & 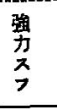 & $\begin{array}{l}\text { v7 } \\
17 \\
9 \\
\text { ขン } \\
\end{array}$ & $\begin{array}{l}\text { 帮变 } \\
\text { 䓃 } \\
\text { ス性 }\end{array}$ & 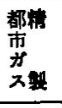 & $\begin{array}{l}\text { 华 } \\
\text { 掌 } \\
\text { 品 }\end{array}$ & $\begin{array}{l}\text { 製 } \\
\text { 来 }\end{array}$ & $\begin{array}{l}\text { 稚 } \\
\text { 労 } \\
\text { 料 }\end{array}$ & $\begin{array}{l}\text { 重 } \\
\text { 㙰 } \\
\end{array}$ & 䑩 & $\begin{array}{l}\text { 石ピ } \\
\text { 油ン } \\
\text { yン } \\
\end{array}$ & $\begin{array}{r}\text { 食碟 } \\
\text { 莱 } \\
\text { 品福 } \\
\end{array}$ & 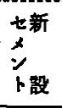 & 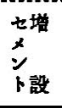 & 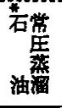 & $\begin{array}{l}\text { 宕パン } \\
\text { 錃ま } \\
\text { 学シ }\end{array}$ & $\begin{array}{r}\text { 食精 } \\
\text { 製 } \\
\text { 品瞊 }\end{array}$ & 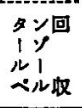 & $\begin{array}{l}\text { 落 } \\
1 \\
\text { 几酒 }\end{array}$ \\
\hline 0 & 80 & 100 & 100 & 0 & 0 & 100 & 100 & 0 & 0 & 50 & 50 & 100 & 100 & 100 & 100 & 0 & 100 & 100 & 100 \\
\hline 0 & 100 & 100 & 100 & $\mathrm{O}$ & 0 & 100 & 80 & 0 & 0 & 0 & 0 & 100 & 100 & 100 & 100 & 33 & - & 100 & 100 \\
\hline 10 & 90 & 70 & 90 & 0 & & 100 & 80 & 0 & 0 & 0 & 0 & 100 & 100 & 100 & 100 & 100 & - & 100 & 100 \\
\hline 50 & 100 & 100 & 100 & 0 & 0 & 100 & 100 & 0 & 0 & 60 & 5 & 100 & 100 & 100 & 100 & 70 & 100 & 80 & 80 \\
\hline 100 & 100 & 100 & 100 & 0 & 0 & 80 & 100 & 0 & 100 & 0 & 50 & 100 & 100 & 100 & - & 0 & 100 & 100 & 100 \\
\hline 80 & 100 & 100 & 100 & & & 40 & 100 & 100 & 50 & 30 & 20 & 100 & 90 & 100 & 100 & 80 & 90 & 100 & 100 \\
\hline 0 & 30 & 30 & 80 & & 0 & 30 & 50 & 70 & 30 & 80 & 20 & 10 & 30 & 40 & 70 & 30 & 10 & 30 & 30 \\
\hline 0 & 30 & 50 & 60 & 0 & 0 & 0 & 50 & 95 & 100 & 0 & 20 & 20 & 20 & 30 & 100 & 100 & 20 & 20 & 20 \\
\hline 80 & 100 & 100 & 100 & 0 & 0 & 50 & 100 & 100 & 80 & 70 & 50 & 95 & 50 & 100 & 100 & 100 & 90 & 80 & 80 \\
\hline 30 & 80 & 100 & 100 & 0 & 0 & 0 & 100 & 100 & 30 & 80 & 0 & 90 & 100 & 100 & 100 & 100 & 95 & 30 & 30 \\
\hline 10 & 80 & 100 & 100 & & & 10 & 100 & 100 & 30 & 70 & o & 70 & 30 & 10 & 50 & 70 & 90 & 30 & 30 \\
\hline 50 & 80 & 100 & 100 & 0 & 0 & 0 & 100 & 100 & 100 & 20 & 0 & 80 & 50 & 60 & 100 & 100 & 40 & 80 & 80 \\
\hline 0 & 40 & 50 & 50 & 0 & 0 & 0 & 100 & 60 & 80 & 20 & 100 & 90 & 20 & 40 & 10 & 0 & 20 & 30 & 30 \\
\hline 0 & 20 & 20 & 40 & & & 0 & 100 & 10 & 80 & 0 & 100 & 20 & 10 & 30 & 10 & 0 & 5 & 20 & 20 \\
\hline 0 & 10 & 5 & 5 & 0 & 0 & 0 & 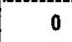 & 5 & 0 & 0 & 100 & 0 & 10 & 10 & 0 & 0 & 5 & 100 & 100 \\
\hline 0 & 0 & 10 & 10 & 0 & 0 & 0 & 0 & 50 & 0 & 0 & 100 & 0 & 10 & 10 & 0 & 0 & 0 & 100 & 100 \\
\hline 0 & 10 & 5 & 10 & & 0 & 0 & 0 & 0 & 0 & 0 & 0 & 0 & 20 & 30 & 100 & 80 & 50 & 10 & 10 \\
\hline 0 & 30 & 40 & 20 & & & 0 & 0 & 0 & 0 & 90 & 0 & 10 & 40 & 40 & 100 & 80 & 5 & 10 & 10 \\
\hline 0 & 15 & 30 & 50 & & 0 & 0 & 0 & 0 & 0 & 90 & 0 & 0 & 80 & 100 & 100 & 80 & 90 & 10 & 10 \\
\hline 0 & 0 & 10 & 10 & & 0 & 0 & 0 & 50 & 0 & 80 & 0 & 0 & 50 & 60 & 100 & 100 & 0 & 0 & 0 \\
\hline 5 & 20 & 10 & 10 & 0 & 0 & 0 & 0 & 0 & 0 & 20 & 0 & 10 & 30 & 40 & 100 & 100 & 0 & 100 & 100 \\
\hline 0 & 20 & 10 & 10 & & & 0 & 0 & 0 & 0 & 80 & 0 & 0 & 30 & 40 & 100 & 100 & 0 & 0 & o \\
\hline 0 & 10 & 5 & 10 & & 0 & 0 & 0 & 0 & 0 & 80 & 0 & 0 & 70 & 80 & 100 & 100 & 0 & 0 & 0 \\
\hline
\end{tabular}

\begin{tabular}{|c|c|c|c|c|c|c|c|c|c|c|c|c|c|}
\hline & 5 & 4 & 5 & 5 & 2 & 1 & & & 3 & 1 & 1 & & 1 \\
\hline & 2 & 3 & & 3 & 4 & 2 & 2 & & 0 & 1 & 4 & & 6 \\
\hline 3 & 0 & 5 & & 6 & 3 & 1 & & & 0 & 1 & 0 & 2 & 2 \\
\hline 1 & 0 & 2 & & 6 & 1 & 1 & & & 1 & 1 & 3 & & \\
\hline 3 & 0 & 3 & 5 & 2 & 5 & 2 & & & 0 & 3 & 2 & 2 & \\
\hline 4 & 0 & 1 & & 8 & 2 & 1 & 1 & & 1 & 2 & 0 & 2 & 1 \\
\hline 0 & 1 & 2 & 3 & 5 & 2 & 5 & & & 3 & & 0 & & 1 \\
\hline 0 & 2 & 2 & & 3 & 3 & 10 & 2 & 3 & 0 & & 5 & & 6 \\
\hline 2 & 1 & 4 & & 6 & 4 & 5 & & & 2 & 1 & 0 & 3 & 2 \\
\hline 1 & 1 & 2 & & 6 & 1 & 10 & & 2 & 1 & 1 & 3 & & \\
\hline 2 & 5 & 3 & 5 & 9 & 10 & 8 & 15 & 3 & 6 & 5 & 6 & 4 & 3 \\
\hline 1 & 2 & 2 & 2 & 3 & 3 & 3 & & 3 & 1 & 1 & 2 & 1 & 1 \\
\hline 1 & 2 & 1 & & 3 & 3 & 3 & 1 & 3 & 1 & 1 & 2 & & 1 \\
\hline 1 & 2 & 1 & & 2 & 3 & 2 & & 3 & 0 & 5 & 2 & & 1 \\
\hline 0 & 0 & 3 & & 0 & 5 & 20 & & & 0 & & 0 & & \\
\hline 2 & 1 & 1 & & 3 & 2 & 4 & 2 & & 2 & & 3 & & 1 \\
\hline & 1 & 2 & & 0 & 5 & 10 & 1 & & 2 & & 0 & & 6 \\
\hline & 4 & 5 & 2 & 0 & 4 & 5 & & 3 & 6 & 1 & 0 & 4 & 2 \\
\hline & 1 & 2 & & 4 & 1 & 10 & & 2 & 1 & 1 & 3 & & \\
\hline & 5 & 3 & 5 & 8 & 13 & 8 & 2 & 3 & 10 & 6 & 3 & 4 & 2 \\
\hline & 2 & 2 & 2 & 1 & 3 & 3 & & $\mathbf{3}$ & 1 & 2 & 1 & & \\
\hline & 2 & 3 & 2 & 2 & 3 & 3 & 1 & $\mathbf{3}$ & 3 & 2 & 1 & 1 & 1 \\
\hline & 2 & 1 & & 2 & 3 & 2 & & 3 & 0 & $\mathbf{5}$ & 0 & & 1 \\
\hline & 0 & 3 & & 0 & 5 & 20 & & & 4 & & 0 & & \\
\hline & 2 & 1 & 1 & 3 & 2 & 4 & 1 & & 2 & 2 & 1 & 8 & 1 \\
\hline
\end{tabular}


II. 化学プラント建設费内訳比享

\begin{tabular}{|c|c|c|c|c|c|c|c|c|c|c|c|c|}
\hline \multirow[b]{2}{*}{ 柿 } & \multirow[b]{2}{*}{ 能 力 } & \multirow[b]{2}{*}{ 全金网) } & \multicolumn{3}{|c|}{ 盽 } & $\lambda$ & \multicolumn{3}{|c|}{ 器 } & \multirow[b]{2}{*}{ 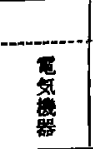 } & \multirow[b]{2}{*}{ 管 } & \multirow[b]{2}{*}{$\begin{array}{l}\text { 䟕 } \\
\text { 架 } \\
\text { 椾 }\end{array}$} \\
\hline & & & 榙 & 交 & 加 & $\begin{array}{l}\text { ポソサ } \\
\text { ソプ1 } \\
\text { プレ } \\
コ ッ\end{array}$ & 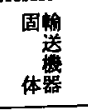 & 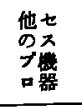 & 器 & & & \\
\hline \multicolumn{13}{|c|}{ [A] 主として流体を扱う壮元 } \\
\hline 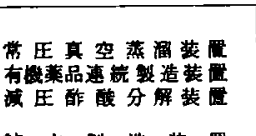 & $\begin{array}{c}30,000 \mathrm{Bbl} / \mathrm{D} \\
60 \mathrm{~T} / \mathrm{M} \\
70 \mathrm{~T} / \mathrm{M}\end{array}$ & $\begin{array}{r}1,167,339 \\
61,533 \\
236,000\end{array}$ & $\begin{array}{l}11.2 \% \\
28.9 \\
9.8 \\
(4)\end{array}$ & $\begin{array}{l}7.8 \% \\
0.2 \\
11.2\end{array}$ & $\frac{6.5 \%}{8.5}$ & $\begin{array}{l}(1) \\
2.4 \% \\
8.9 \\
11.6 \\
(5)\end{array}$ & $\begin{array}{l}-\% \\
0.9 \\
1.7\end{array}$ & $\begin{array}{l}-\% \\
9.5 \\
1.3\end{array}$ & $\begin{array}{c}6.5 \% \\
20.4 \\
6.4\end{array}$ & $\frac{-\%}{4.1}$ & $\begin{array}{l}12.1 \% \\
10.6 \\
20.8\end{array}$ & $\begin{array}{l}1.5 \% \\
7.0 \\
0.6\end{array}$ \\
\hline 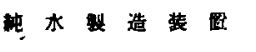 & $1,700 \mathrm{~T} / \mathrm{D}$ & 30,250 & 72.8 & & & 6.6 & & & 9.9 & 0.7 & 1.0 & - \\
\hline 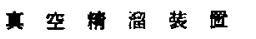 & $25.9 \mathrm{~T} / \mathrm{D}$ & 47,540 & 16.0 & 7.7 & - & 4.9 & - & 14.93 & 16.3 & 0.53 & 13.5 & 4.2 \\
\hline$"$ & $25.9 "$ & 59,450 & 16.1 & 9.5 & - & 6.5 & - & 13.6 & 13.0 & 1.2 & 14.9 & 4.2 \\
\hline 医来品 “ R” 合成㳖量 & $1 \mathrm{~T} / \mathrm{D}$ & $\begin{array}{r}40,000 \\
709,220\end{array}$ & $\begin{array}{l}34.3 \\
32.4\end{array}$ & $\begin{array}{l}4.2 \\
0.8\end{array}$ & $\overline{-}$ & $\begin{array}{r}0.5 \\
6.2\end{array}$ & $\begin{array}{l}3.0 \\
0.2\end{array}$ & $\begin{array}{r}8.6 \\
18.9\end{array}$ & $\begin{array}{l}1.3 \\
2.5\end{array}$ & $\frac{2.8}{2}$ & $\begin{array}{r}5.6 \\
11.4\end{array}$ & $\begin{array}{l}8.7 \\
1.1\end{array}$ \\
\hline 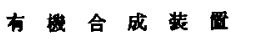 & $11 \mathrm{~T} / \mathrm{D}$ & 406.400 & 16.2 & 11.2 & - & 11.7 & 0 & 1.0 & 7.7 & - & $\underbrace{21.9}$ & 8.0 \\
\hline 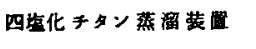 & $350 \mathrm{~T} / \mathrm{M}$ & 49,200 & 18.0 & 17.8 & 7.7 & \multicolumn{2}{|c|}{8.2} & 8.4 & 2.3 & 4.3 & \multicolumn{2}{|c|}{10.7} \\
\hline 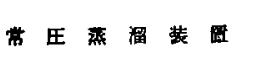 & & $1,126,535$ & 11.02 & 22.02 & 16.46 & $\stackrel{(12)}{10.20}$ & - & - & 4.91 & 1.91 & 12.27 & 4.50 \\
\hline 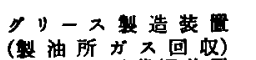 & $7 \mathrm{~T} / \mathrm{D}$ & 17,833 & 19.0 & 8.3 & 16.8 & $(18)^{6.5}$ & - & 1.9 & $(19)^{1.7}$ & $(20)^{4.8}$ & 0.5 & 1.5 \\
\hline 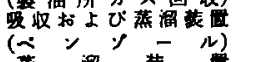 & $750 \mathrm{Bbl} / \mathrm{D}$ & 106,000 & 7.0 & 10.3 & - & & - & - & (19) & & 10.6 & 2.9 \\
\hline 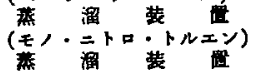 & $\begin{array}{l}65 \mathrm{~T} / \mathrm{D} \\
10 \mathrm{~T} / \mathrm{D}\end{array}$ & 53,400 & $\begin{array}{l}19.3 \\
18.2\end{array}$ & $\begin{array}{l}9.5 \\
6.0\end{array}$ & - & $\begin{array}{c}5.1 \\
1.6\end{array}$ & - & $\begin{array}{l}- \\
1.3\end{array}$ & $\begin{array}{r}25.8 \\
119) \\
15.6\end{array}$ & $\frac{(24)}{1.8}$ & $\begin{array}{r}7.0 \\
21.1\end{array}$ & $\begin{array}{l}4.0 \\
3.8\end{array}$ \\
\hline 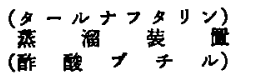 & $150 \mathrm{~T} / \mathrm{D}$ & 146,000 & 11.1 & 4.1 & 13.8 & $\begin{array}{l}(18) \\
6.1 \\
(23)\end{array}$ & $\begin{array}{l}\text { (18) } \\
3.0\end{array}$ & - & $\begin{array}{l}(19) \\
14.7 \\
(19)\end{array}$ & ${ }_{1.5}^{(20)}$ & 13.4 & 2.0 \\
\hline 溜柿 & $100 \mathrm{~T} / \mathrm{D}$ & 15,500 & 19.2 & 13.5 & - & $\begin{array}{l}4.8 \\
(23)\end{array}$ & - & - & $\begin{array}{l}12.9 \\
(19)\end{array}$ & - & $(27)^{11.9}$ & 5.7 \\
\hline 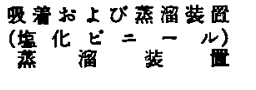 & $\begin{array}{c}50,000 \mathrm{NM}^{3} / \mathrm{D} \\
120 \mathrm{~T} / \mathrm{D}\end{array}$ & $\begin{array}{r}836.000 \\
60.500\end{array}$ & $\begin{array}{r}1.7 \\
10.1\end{array}$ & $\begin{array}{r}0.8 \\
21.4\end{array}$ & $\begin{array}{l}3.0 \\
-\end{array}$ & $\begin{array}{l}1.4 \\
(18) \\
2.6\end{array}$ & - & - & $\begin{array}{c}3.6 \\
14.6 \\
(19)\end{array}$ & $\frac{(24)^{-}}{1.8}$ & $\begin{array}{l}60.2 \\
14.0\end{array}$ & $\begin{array}{l}0.7 \\
5.0\end{array}$ \\
\hline 反応打上び蒸淄装医 & $60 \mathrm{~T} / \mathrm{D}$ & 262,000 & 28.6 & 7.5 & - & 15.2 & - & 0.8 & 4.5 & 8.2 & 9.6 & 1.3 \\
\hline 畷 着柿 & $1,000 \mathrm{~kg} / \mathrm{D}$ & 24,000 & 11.5 & 2.0 & - & (23) 2.9 & - & - & $\stackrel{(19)}{41.5}$ & - & 15.9 & - \\
\hline 化 & $1 \mathrm{~T} / \mathrm{M}$ & 76,950 & 29.6 & 2.9 & - & 5.8 & - & 38.3 & 3.4 & 0.5 & 6.5 & - \\
\hline 面油分解芸是 & $110 \mathrm{KL} / \mathrm{D}$ & 820.000 & 26.4 & 6.9 & 1.3 & $\begin{array}{l}16.0 \\
(19)\end{array}$ & - & 0.5 & 6.1 & 2.4 & 11.0 & 0.5 \\
\hline 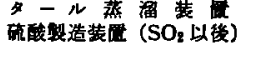 & $\begin{array}{r}135 \mathrm{~T} / \mathrm{D} \\
3,000 \mathrm{~T} / \mathrm{M}\end{array}$ & $\begin{array}{l}114,169 \\
381,081\end{array}$ & $\begin{array}{l}15.5 \\
26.2\end{array}$ & $\begin{array}{r}5.6 \\
13.7\end{array}$ & $\stackrel{14.9}{-}$ & $\begin{array}{r}11.2 \\
2.1 \\
\end{array}$ & $\begin{array}{l}3.5 \\
1.5 \\
\end{array}$ & $\begin{array}{c}0 \\
17.7\end{array}$ & $\begin{array}{r}18.0 \\
0.9\end{array}$ & $\overline{4.9}$ & $\begin{array}{r}10.3 \\
6.5\end{array}$ & $\begin{array}{l}4.1 \\
2.9\end{array}$ \\
\hline 油脂のヶン化 & & $39,880.8$ & 31.6 & 7.3 & - & 1. & & - & - & - & 25.6 & 5.5 \\
\hline
\end{tabular}

[B] 主として固体を扱う薄是

\begin{tabular}{|c|c|c|c|c|c|c|c|c|c|c|c|c|}
\hline 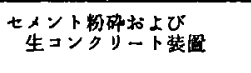 & $\begin{array}{l}500 T / D \\
500 \mathrm{M}^{3 / D}\end{array}$ & 487,000 & - & - & - & - & 6.4 & - & 0.2 & 6.1 & 0.3 & 16.4 \\
\hline 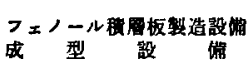 & $\begin{array}{l}60 \mathrm{~T} / \mathrm{M} \\
20 \mathrm{~T} / \mathrm{M}\end{array}$ & $\begin{array}{l}120,000 \\
220,000\end{array}$ & $\overline{1.8}$ & $\overline{-}$ & $\overline{-}$ & $\begin{array}{l}6.7 \\
5.0\end{array}$ & $\overline{1.8}$ & $\begin{array}{r}(30) \\
51.7 \\
45.4 \\
(32)\end{array}$ & $\begin{array}{l}2.5 \\
0.4\end{array}$ & $\begin{array}{l}2.5 \\
1.8\end{array}$ & $\begin{array}{l}4.2 \\
2.0\end{array}$ & $\begin{array}{l}0.8 \\
0.4\end{array}$ \\
\hline 世*ン & $35,000 \mathrm{~T} / \mathrm{M}$ & $2,088,000$ & - & - & 16 & 0.8 & 4 & 10 & 2 & 12 & 0.7 & 0.4 \\
\hline
\end{tabular}

[C] 流体およひ固体を扱う装是

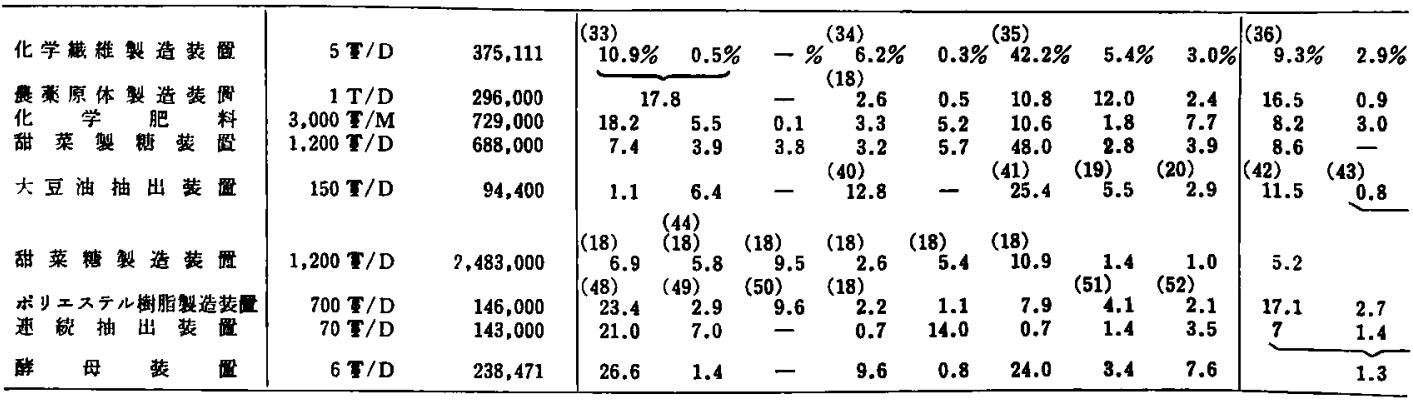


一般に化学ブラントの建設望の概

\begin{tabular}{|c|c|c|c|c|c|c|c|c|c|c|}
\hline$I$ & & $*$ & & . & & & & 術 & の & \\
\hline 据 & 湓 & 善 & 寓照 & 部 & 速 & 基 & $\begin{array}{l}\text { 設 } \\
\text { 計 }\end{array}$ & $\begin{array}{l}I \\
\text { J }\end{array}$ & 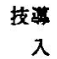 & $\begin{array}{l}\text { そ } \\
\text { の }\end{array}$ \\
\hline 付 & 梁 & 震 & 妿明 & 变 & 家 & 硺 & 料 & 费 & 行㧧 & 他 \\
\hline
\end{tabular}

\begin{tabular}{|c|c|c|c|c|c|c|c|c|c|c|}
\hline $\begin{array}{l}2.6 \% \\
1.2 \\
1.5\end{array}$ & $\begin{array}{l}2.4 \% \\
0.2 \\
1.1\end{array}$ & $\begin{array}{l}0.3 \% \\
0.1 \\
0.4\end{array}$ & $\begin{array}{l}0.6 \% \\
3.7 \\
1.6\end{array}$ & $\begin{array}{l}-\% \\
0.4 \\
1.0\end{array}$ & $\begin{array}{l}1.7 \% \\
5.5 \\
14.0\end{array}$ & $\begin{array}{l}1.6 \% \\
0.5 \\
2.0\end{array}$ & $\begin{array}{c}13.6 \% \\
1.3 \\
\end{array}$ & $\begin{array}{c}(2) \\
13.7 \% \\
1.1 \\
\end{array}$ & - & $\begin{array}{l}\text { (3) } \\
15.6 \% \\
2.0 \\
-\end{array}$ \\
\hline 1.3 & - & 0.3 & 2.5 & 0.3 & 1.0 & 2.3 & \multicolumn{2}{|c|}{1.0} & - & 0.3 \\
\hline 4.84 & 2.1 & - & - & - & - & - & 2.1 & 42 & 8.7 & - \\
\hline 3.9 & 5.0 & - & - & - & - & - & 1.7 & $\begin{array}{l}3.4 \\
(8)\end{array}$ & - & $(9)^{7.0}$ \\
\hline $\begin{array}{l}0.4 \\
1.8\end{array}$ & $\begin{array}{l}1.7 \\
2.2\end{array}$ & $\begin{array}{l}0.25 \\
0.5\end{array}$ & $\begin{array}{r}1.3 \\
3.8 \\
(11)\end{array}$ & $\begin{array}{l}0.25 \\
1.3\end{array}$ & $\begin{array}{l}16.2 \\
13.6\end{array}$ & $\begin{array}{l}8.7 \\
1.7\end{array}$ & 1.4 & $=$ & $=$ & $\begin{array}{l}0.8 \\
1.6\end{array}$ \\
\hline 1.2 & 2.3 & 0.1 & 4.3 & 6.7 & 3.3 & 4.0 & 0.4 & - & - & - \\
\hline 1.6 & 1.8 & 0.7 & 1.9 & 0.8 & \multicolumn{2}{|c|}{$\begin{array}{l}15.2 \\
(13)\end{array}$} & & (14) & - & ${ }_{(15)}^{0.6}$ \\
\hline $\begin{array}{l}1.67 \\
7.4\end{array}$ & ${ }^{(16)}{ }_{1.7}^{3.78}$ & $\begin{array}{c}0.04 \\
(16) \\
1.1\end{array}$ & $\begin{array}{l}0.48 \\
3.6\end{array}$ & $\begin{array}{c}0.14 \\
(16) \\
0.6\end{array}$ & ${ }_{23.0}^{(17)}$ & 1.6 & $\begin{array}{l}0.62 \\
-\end{array}$ & $\begin{array}{c}1.67 \\
-\end{array}$ & - & 8.33 \\
\hline 1.2 & 0.9 & 0.2 & - & - & 1.4 & 5.6 & & & - & - \\
\hline $\begin{array}{l}2.0 \\
2.2\end{array}$ & 1.0 & 0.5 & - & - & - & - & $\begin{array}{c}20.0 \\
(21) \\
20.0\end{array}$ & $\begin{array}{c}5.1 \\
(25) \\
2.5\end{array}$ & - & - \\
\hline 2.0 & 2.6 & 0.5 & - & - & - & - & $\begin{array}{l}(21) \\
20.0 \\
(21)\end{array}$ & $\begin{array}{l}(26) \\
5.2 \\
(22)\end{array}$ & - & - \\
\hline 1.3 & 1.4 & 0.4 & - & - & - & - & $\begin{array}{c}20.0 \\
(21)\end{array}$ & $\begin{array}{l}8.9 \\
(22)\end{array}$ & - & - \\
\hline 1.7 & $\begin{array}{l}0.1 \\
3.7\end{array}$ & 0.5 & - & - & - & - & $\begin{array}{c}20.0 \\
(21) \\
20.0\end{array}$ & $\begin{array}{c}7.9 \\
(22) \\
4.6\end{array}$ & - & - \\
\hline 1.1 & 0.3 & 0 & - & - & - & - & $\begin{array}{c}20.0 \\
(21)\end{array}$ & $\begin{array}{r}2.8 \\
(22)\end{array}$ & - & - \\
\hline 0.4 & 0.4 & 0.2 & - & - & - & - & 20.0 & 5.2 & - & - \\
\hline 28$)^{2.1}$ & 0.8 & 1.0 & & & - & - & (28) & $(28)^{6.5}$ & - & - \\
\hline & 1.3 & 0.1 & $\begin{array}{l}6.1 \\
(29)\end{array}$ & 2.0 & 1.0 & 4 & - & - & 9.8 & 4.2 \\
\hline $\begin{array}{l}1.1 \\
5.5\end{array}$ & $\begin{array}{l}2.5 \\
1.3\end{array}$ & $\begin{array}{l}0.5 \\
0.1\end{array}$ & $\begin{array}{l}1.3 \\
1.9\end{array}$ & $\begin{array}{l}1.5 \\
0.6\end{array}$ & $\begin{array}{l}3.5 \\
4.9\end{array}$ & $\begin{array}{l}3.5 \\
6.3\end{array}$ & $1^{1.1}$ & $\stackrel{0.7}{-}$ & $\begin{array}{l}1.2 \\
0.9 \\
\end{array}$ & $\overline{2.2}$ \\
\hline 1.3 & 4.9 & 0.4 & & & 8.3 & 1.5 & 3.0 & 1.3 & & 7.4 \\
\hline
\end{tabular}

\begin{tabular}{lllllll|llll}
\hline 3.0 & - & 0.1 & 9.2 & - & 15.0 & 19.0 & - & - & - & 24.3 \\
3.3 & 0.4 & 0.4 & 4.2 & - & 20.8 & 2.5 & - & - & - & - \\
0.9 & 0.2 & 0.2 & 8.6 & 0.2 & 30.0 & 1.3 & - & - & - & - \\
3 & 0.6 & 0.1 & 2.6 & 0.4 & 22 & 2 & 0.9 & 0.7 & 6 & 16 \\
\hline
\end{tabular}

\begin{tabular}{|c|c|c|c|c|c|c|c|c|c|c|}
\hline \multirow[b]{2}{*}{$2.6 \%$} & \multirow[b]{2}{*}{$2.0 \%$} & \multirow[b]{2}{*}{0.9} & \multirow[b]{2}{*}{$3.2 \%$} & \multirow[b]{2}{*}{$0.5 \%$} & \multicolumn{2}{|r|}{ (37) } & \multirow{2}{*}{$\begin{array}{l}(38) \\
0.2 \%\end{array}$} & \multirow[b]{2}{*}{$-\%$} & \multicolumn{2}{|c|}{ (39) } \\
\hline & & & & & $7.7 \%$ & $1.6 \%$ & & & $-\%$ & $0.6 \%$ \\
\hline 1.7 & 1.1 & 0.3 & 5.3 & 1.8 & 13.0 & 1.0 & - & - & 12.2 & 0.1 \\
\hline 0.8 & 2.1 & 0.4 & 3.3 & 0.8 & 13.1 & $\mathbf{1 5 . 5}$ & 0.4 & - & 一 & - \\
\hline 6.1 & & 0.65 & - & 0.65 & - & - & 1.6 & 1.1 & - & - \\
\hline 2.1 & 2.7 & 0.4 & - & - & - & - & 20.0 & 8.4 & - & - \\
\hline .2 & 0.4 & 0.2 & 4.4 & 0.2 & 26.2 & (45) & 0.5 & $\begin{array}{r}(46) \\
6.7 \\
0.9\end{array}$ & & ${ }_{6.1}^{(47)}$ \\
\hline \multirow{3}{*}{$\begin{array}{l}0.7 \\
3.5\end{array}$} & 1.4 & 0.2 & 2.1 & 1.0 & $2 \theta$ & & 1.0 & - & - & - \\
\hline & 2.1 & 0.7 & 2.1 & 7.0 & 10.5 & 3.5 & 7.0 & 3.5 & 3.5 & - \\
\hline & 0.3 & - & 1.8 & - & 23 & & - & - & - & - \\
\hline
\end{tabular}

算を行な弓場合に，塔槽類，路独機 器類など睛入機器類の価格は比較的 正確に求められるが，これに伴 5工 事費，技術费その他はなかなか润め ない。その実龍を知るための調查結 果が本表である。然料を提供してい たたいた会社数は 29 社，件数は 39 件に上った。

東計は総頖に対する条内訳別の\% で示してある。これを睡入機器に対 する\%，あるいはその他の集計方法 に掺算すればなお便利な場合もあろ 5 。

注：

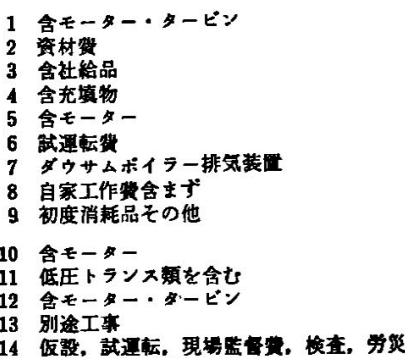

運期, 一般管理窝

16 予算

17 䅂設, 改造

18 含モーター

19 含計装工本

20 含酷力照用工

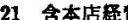

22 含遇嵝，仮設，藏運赈，保險

23 含七ーター, 奄気工事

24 含勏力工束

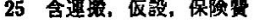

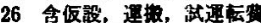

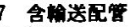

28 器に含めておる

29 含電気瀻器

30 昍品改造

31 キルン

$32 \div$ ×

33 内タンク䅡 $4.8 \%$

34 内命柬 $2.0 \%$

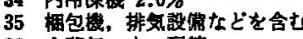

36 含疲気，水，期管

37 含タンク，诺，基喽 $(0.7 \%)$

38 犮屋のみ

39 㭪隹工具その他

40 含モーター设速搂

41 抽出, 啳処理，回収荒薢など

42 含云策落典

43 含運転睭整

44 含协用缺, 結晶缶

45 含機栈基硔, 屋外權菜物

46 路 装

47 工垛数地, 铁道数颜

48 反応釜

49 コンデンサー、リボイラーその他

50 タ゚ウサムボイラー

51 含タンク影是嫫など

52 主として树料费

53 支 給 


\section{III. 各 種 化 学 機器 の価格}

多数の代表的化学機器についてフンケートを㹉願いしたか，比較的凟料が多く果まったものに対して， その機器つ代芘的能力值とコストの関係を対数プロットしたのが以下に揭げる結果である。

化学機器の価格推算法としては

$$
E_{b}=E_{a}\left(\frac{C_{b}}{C_{a}}\right)^{n}
$$

(ただし $C_{a}, C_{b}$ はそれそれ機器 $a, b$ の容量， $E_{a}, E_{b}$ はそれぞれ $a, b$ の洒格)なる式におりる $n$ の值

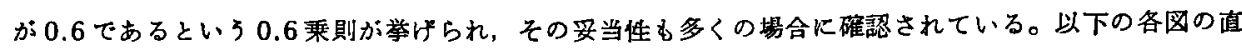
線の傾斜がこの $の$ の值になるが，ここに挙げた各種機器の価格を推算するのに，それぞれの機器に対し て得られるnの値を使用することは十分有用であると思5。

たた調査結果を整理するために，設計や仕様の細かい差異なとは無視した点や，その他把握し難い多 くの因子が含まれている関係上，グラフからも判るようにかなりのバラッキがある。したがって以下に 示すグラフより価格の絶対値を算出することは，この程度の凅料では無理であると判断せさるを得ない。 むし洒格の䋓刘值を求めるために使用する場合には，この点十分留意されることを希望する。

な打俇格は経清企画庁調查料の「機峨卸壳物価指数」により，すへて1960年の価格に換算した。
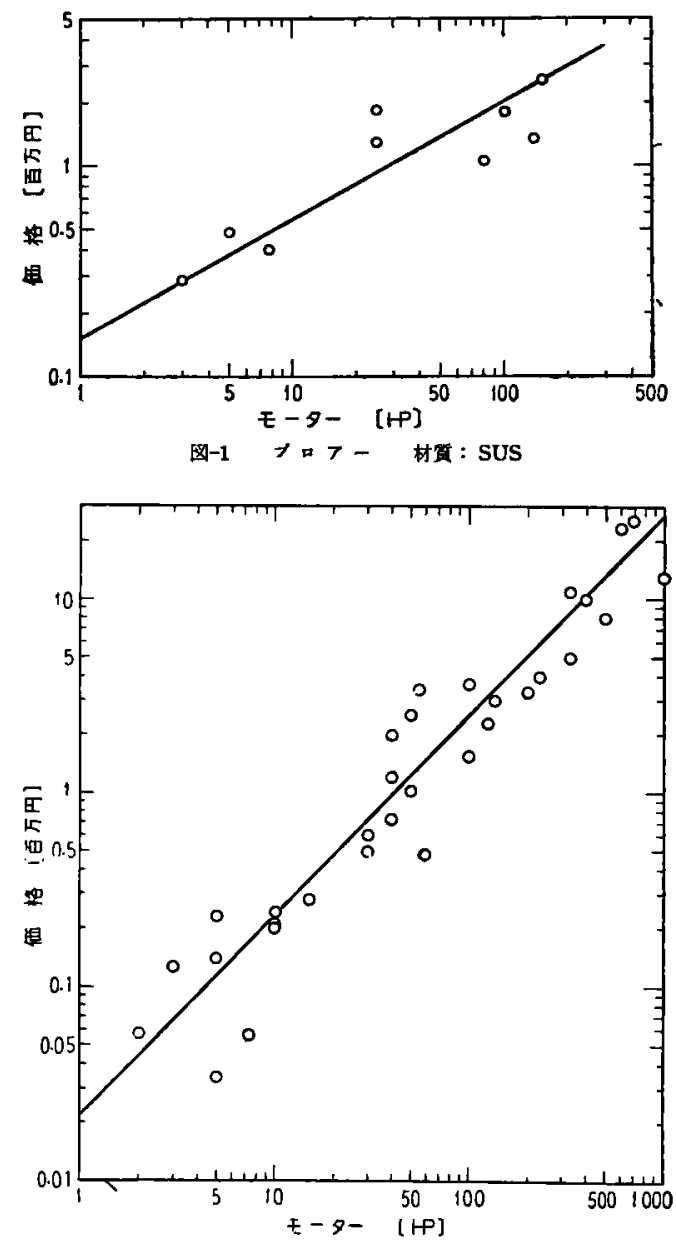

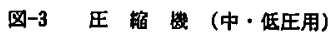
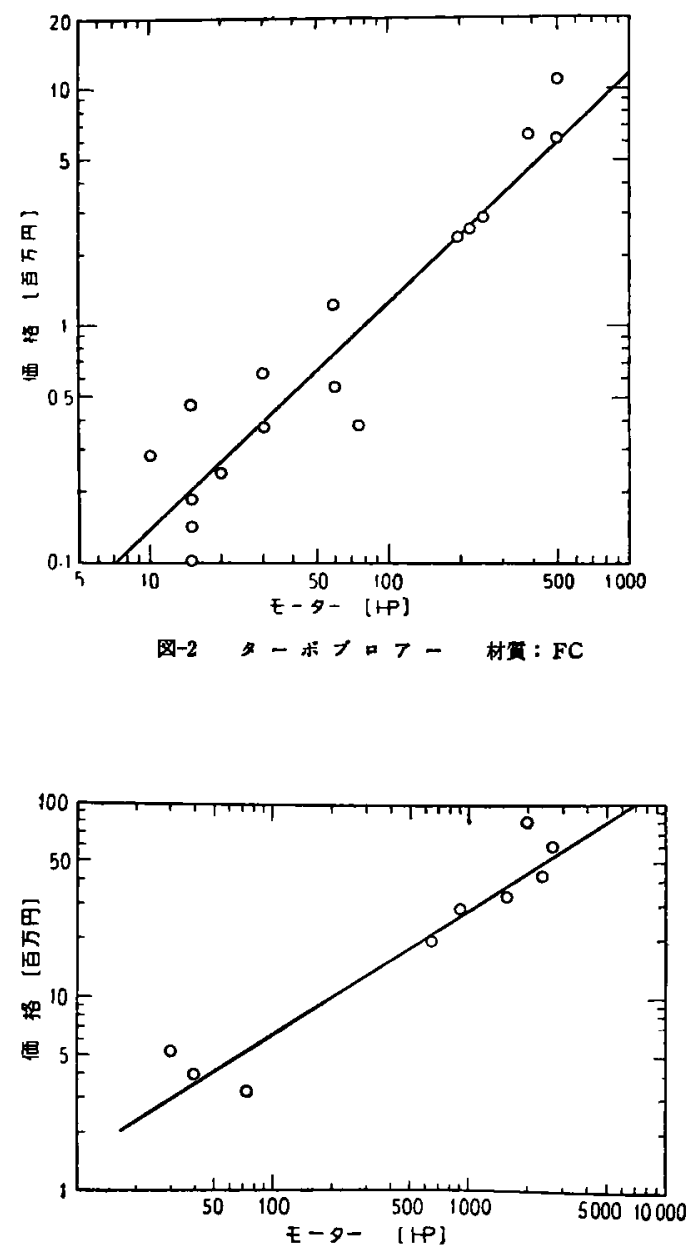

因-4 王樎 (商王用) 

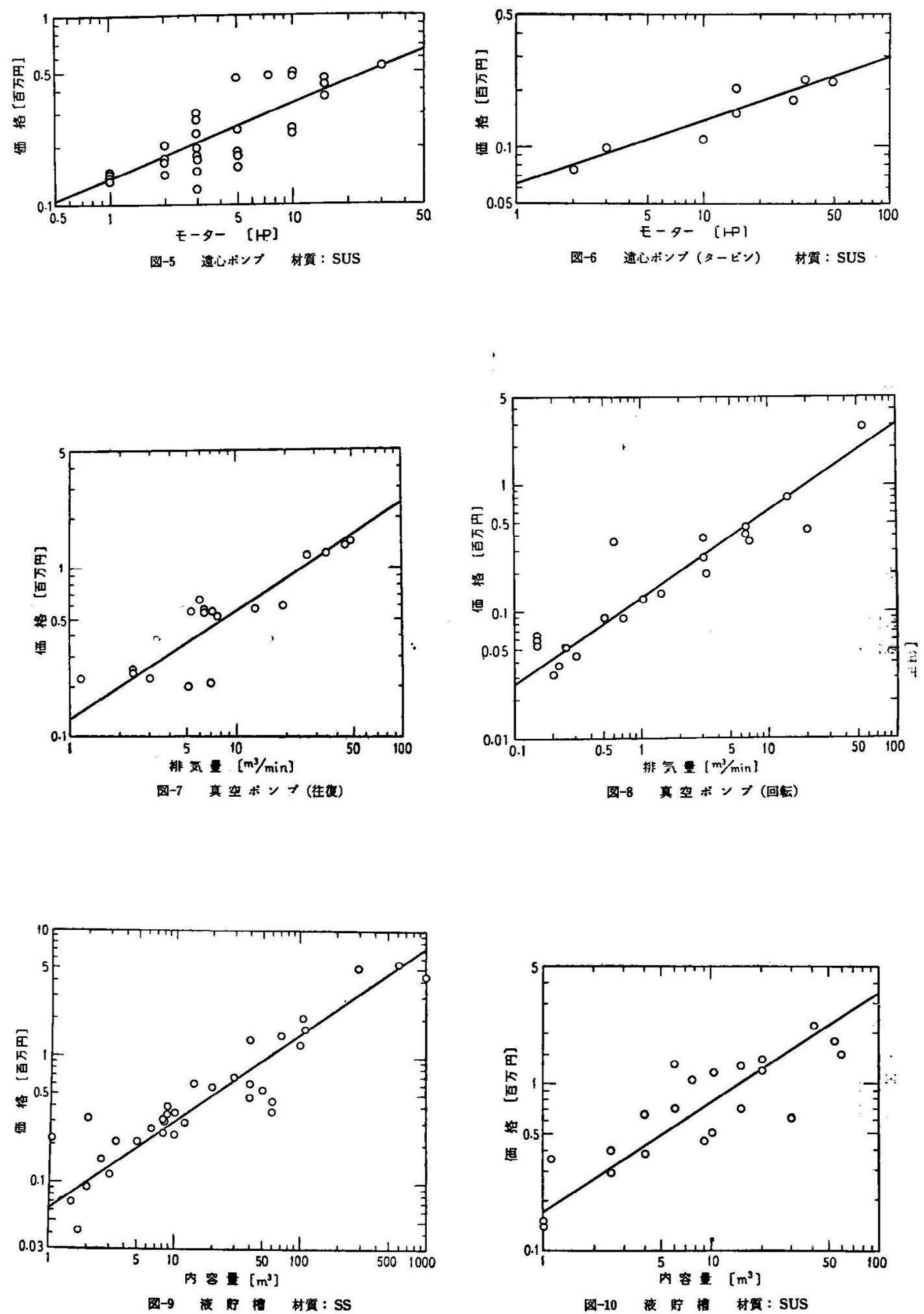

第 24 巻 第 11 号 (1960) 

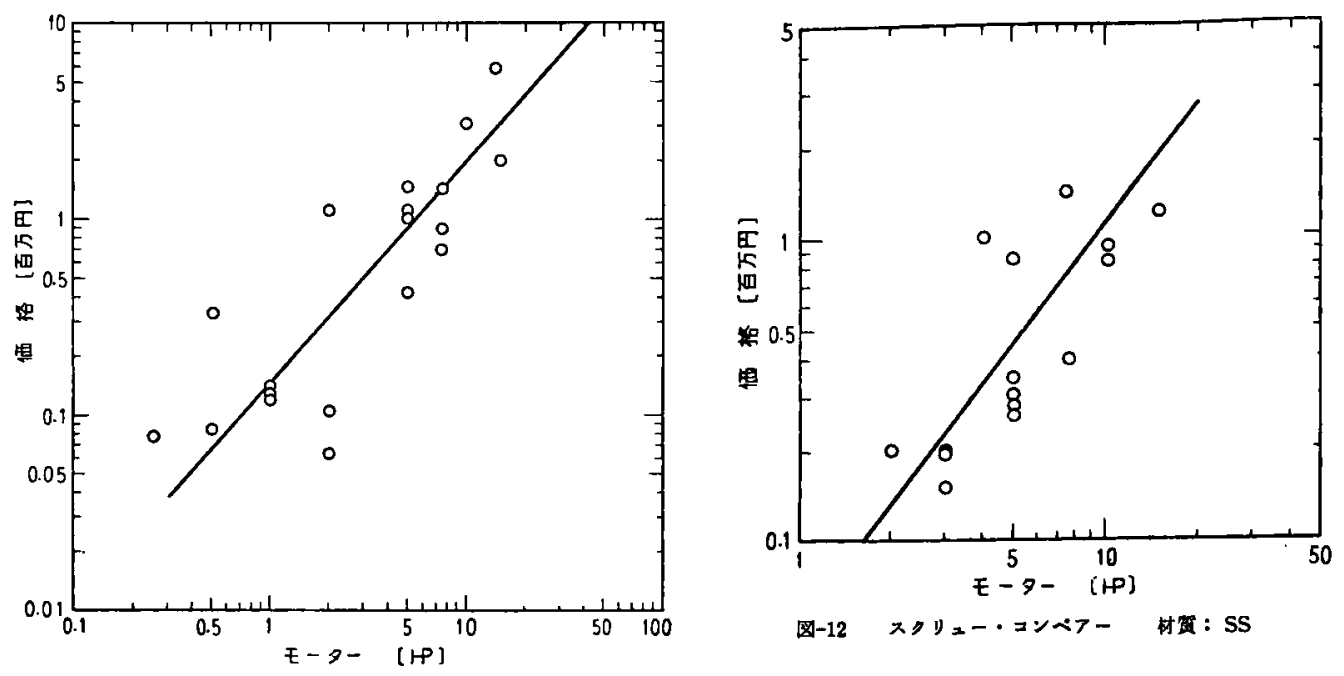

困-11 ベルト・コンベ7ー 材賁：SS
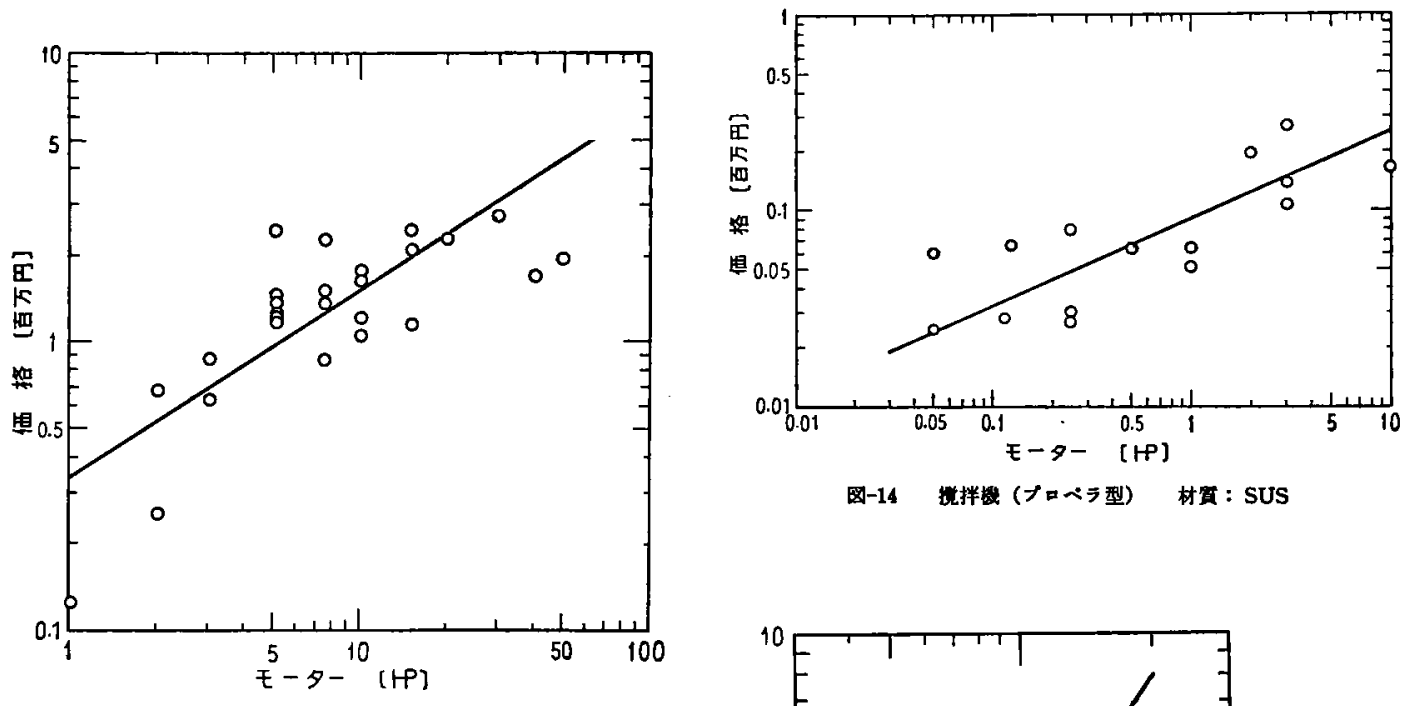

图-14筧洋楼（プロベ）材算：SUS

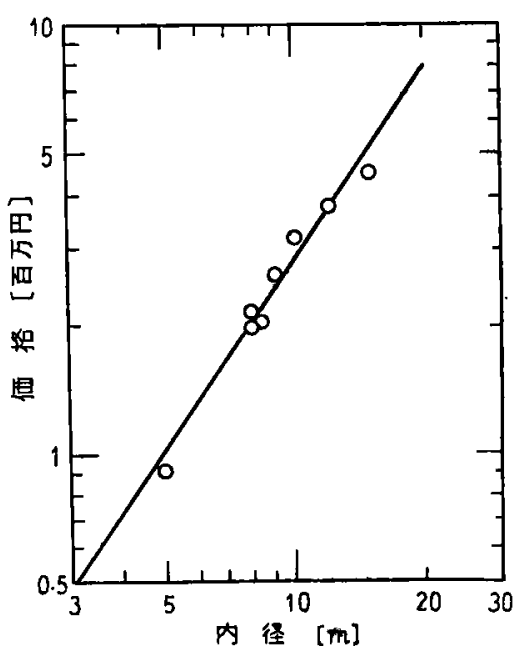

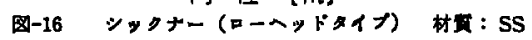




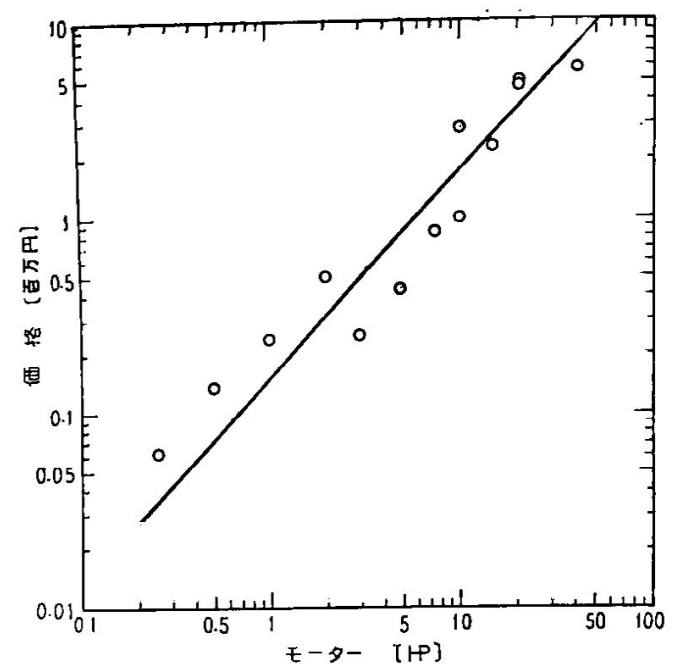

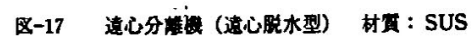

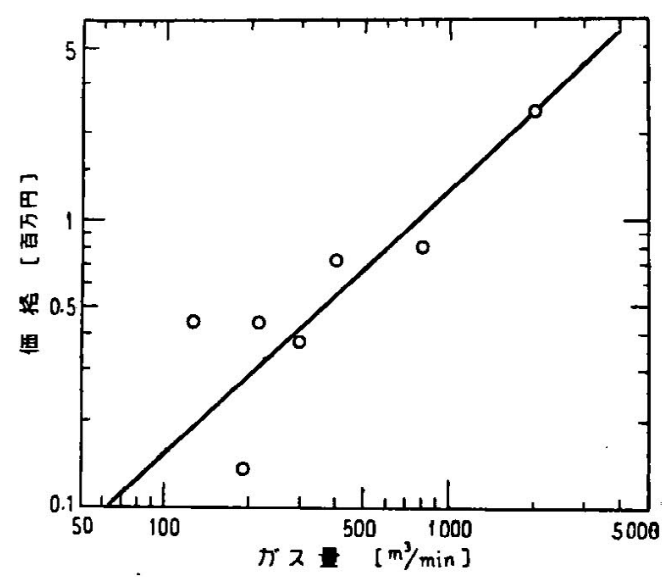

因-19 サ1クロン 材䨘: SS

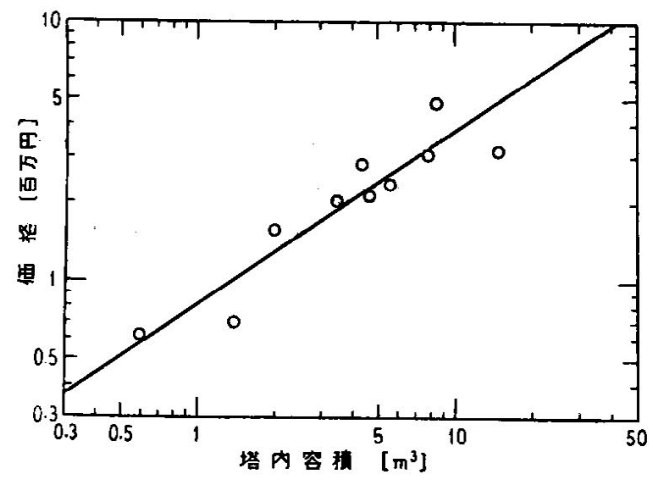

因-21多孔板紫村霓: SUS
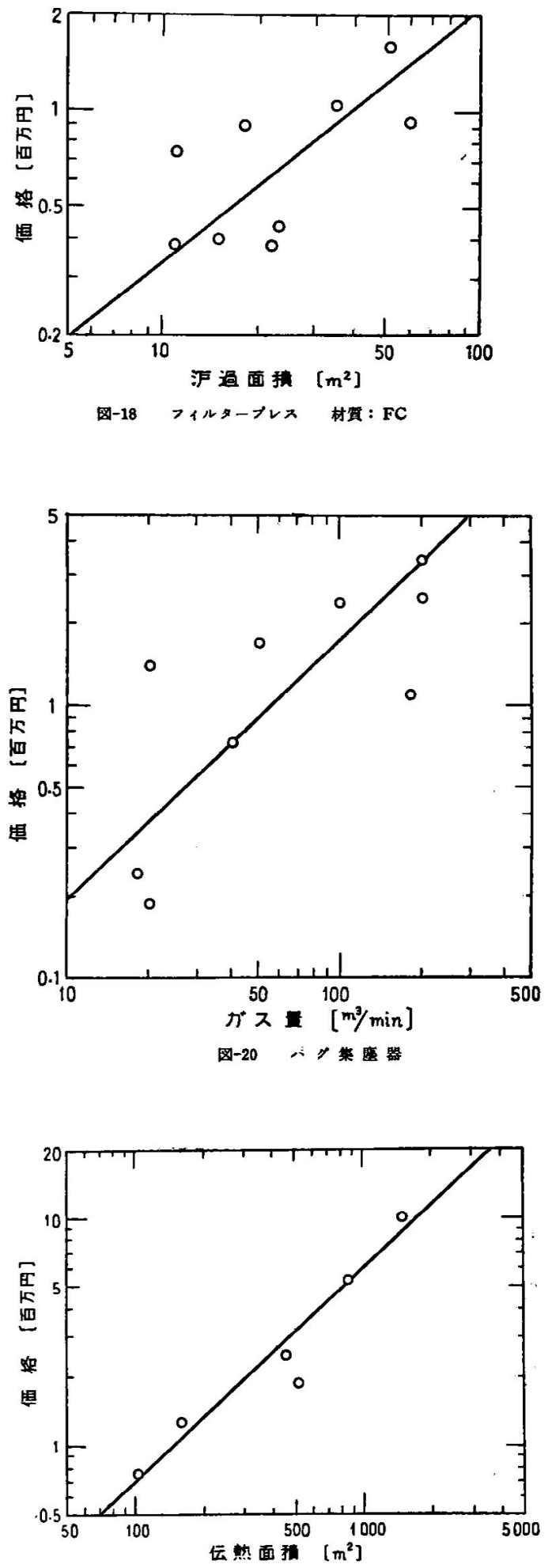

因-22葬替器（カランドリフ型）材貝：SUS 


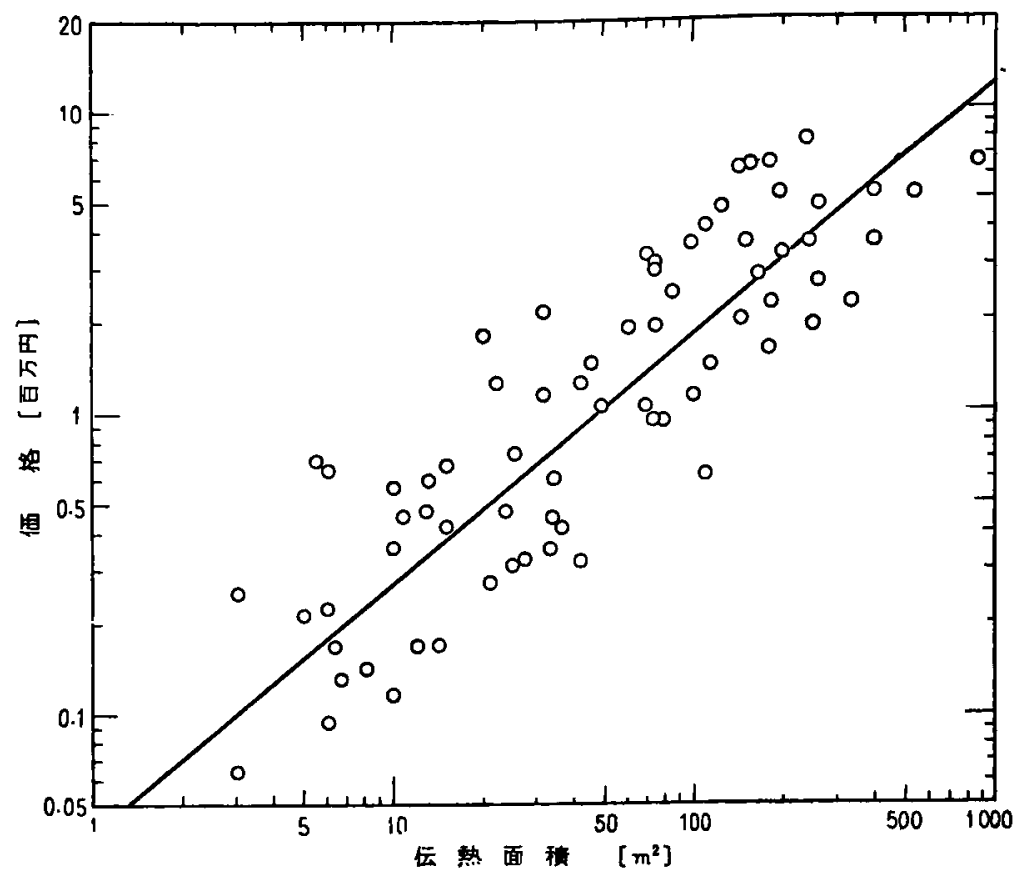

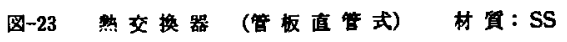

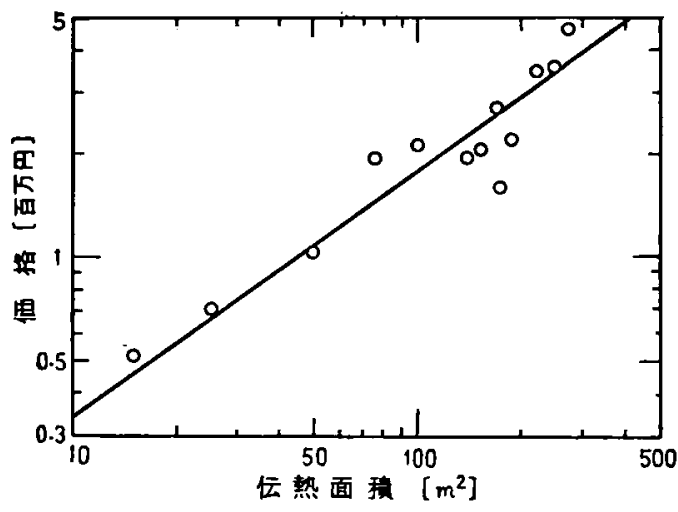

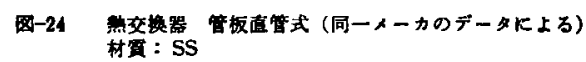

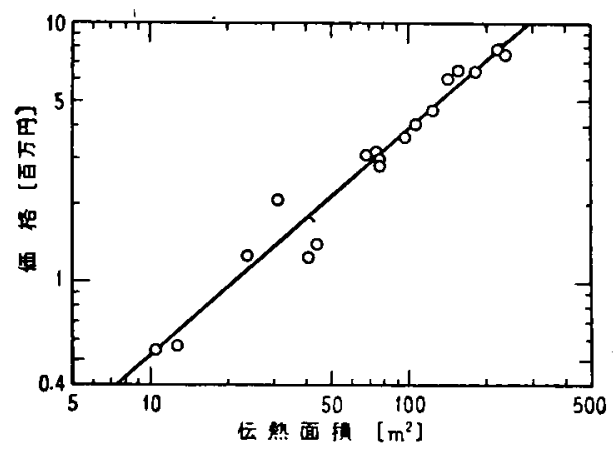

图-26 交交器管板直管式（同ーニーザのテータによる）

材宽：SS

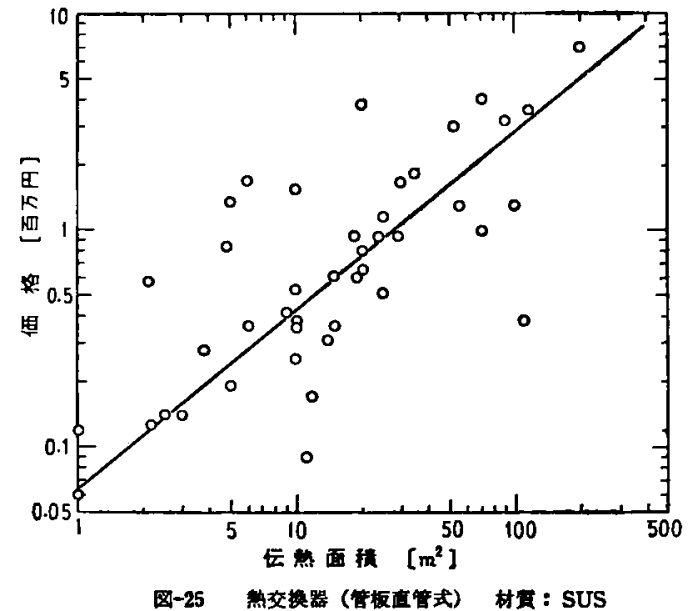

因-25 筒交器（管板直管式）材宣：SUS 


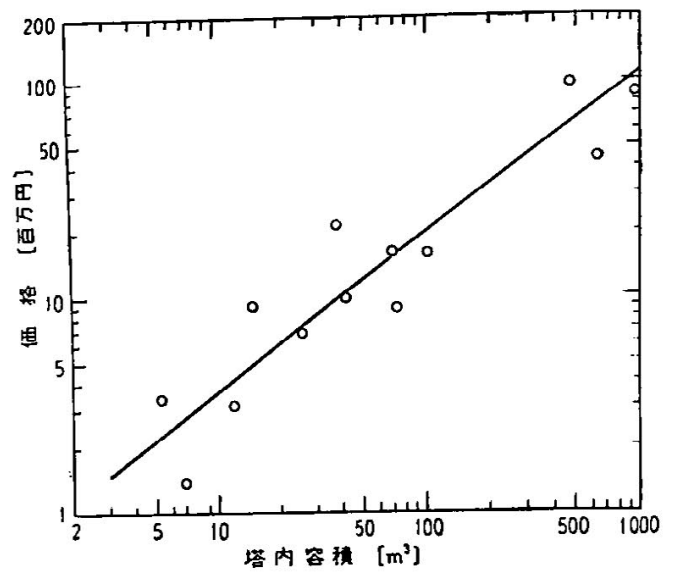

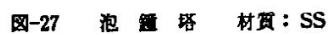

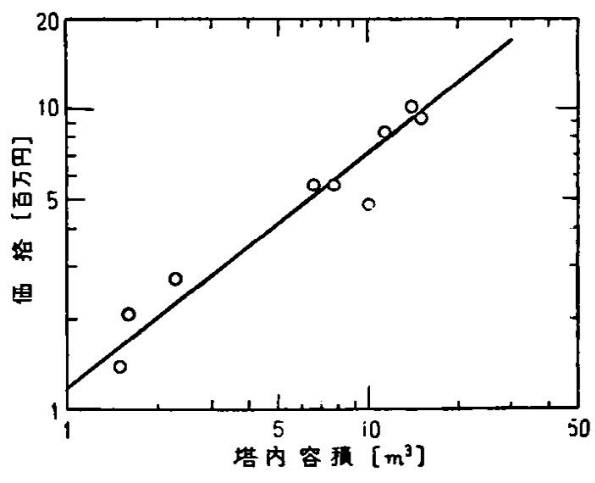

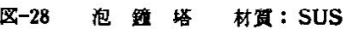

IV. ユーティリティ関係設備の建設霬とコスト

1.四表の作製にあたり，2，3飛び離れた位置に来たすのは省略した。

2. 燃燒装置はデータ不足により作製不能のため除外した。

3. 蒸気, 㫣力, 用水の各単価の最低值, 最高値, 平均値は下記のとおりである。

\begin{tabular}{|c|c|c|c|c|}
\hline 程 & 䕱 & 最 & 最 & 平 \\
\hline 蒸 & $\mathrm{M} / \mathrm{ton}$ & 500 & 2,131 & 980 \\
\hline 電 力 & $\mathrm{Mg} / \mathbf{k W h}$ & 1.47 & 10 & 5.25 \\
\hline 用 水 & $\mathrm{P} /$ ton & 2 & 19.20 & 5.90 \\
\hline
\end{tabular}

4. 25 年から 35 年の間の物価変動を補正するため、経济企画庁調查賀料の「機械卸 売物価指数」により，すへて昭和 35 年に捥算した。

5. 回答会社数 23 社

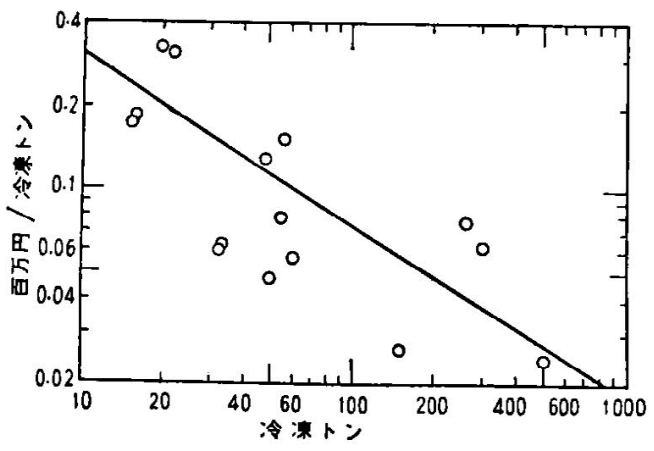

图-29 合 却茷

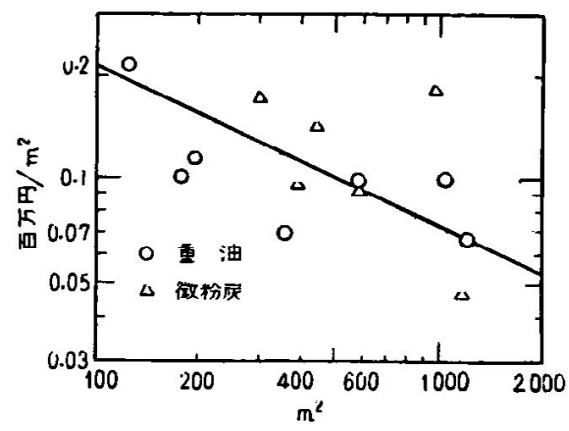

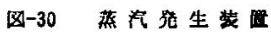




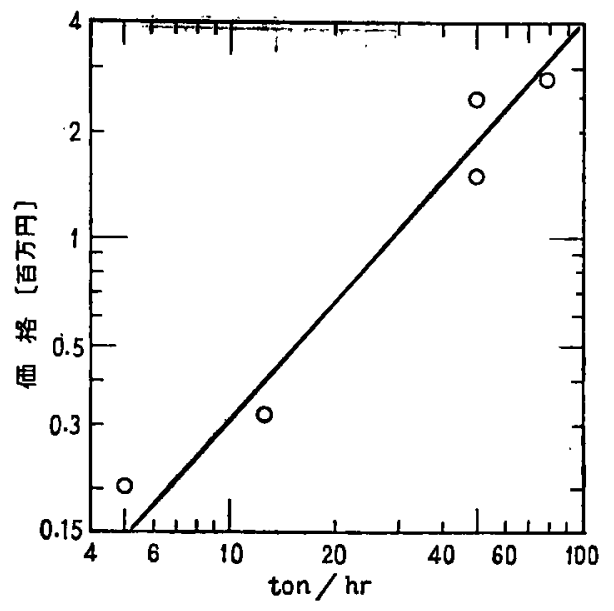

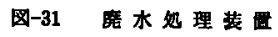

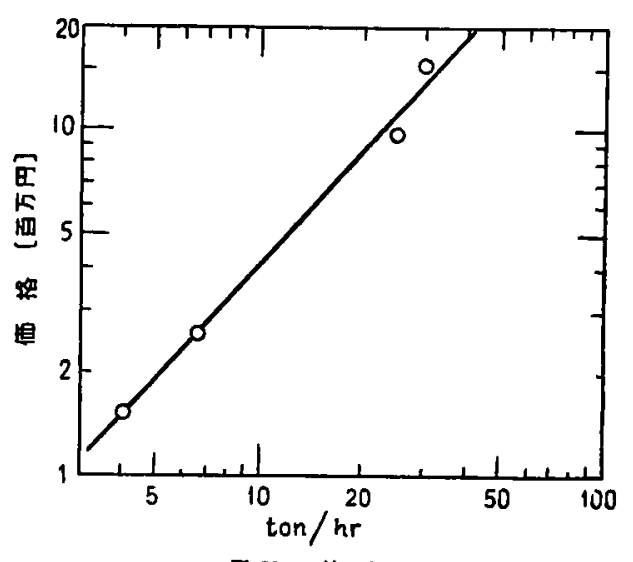

四-33純水索

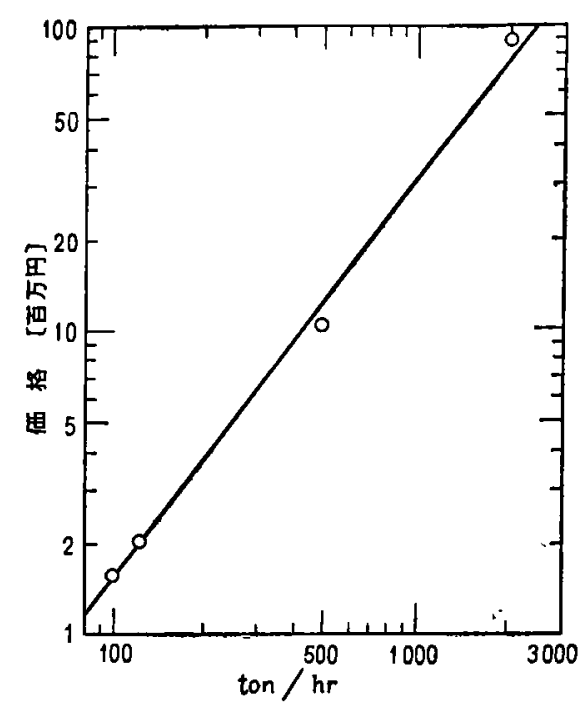

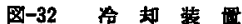

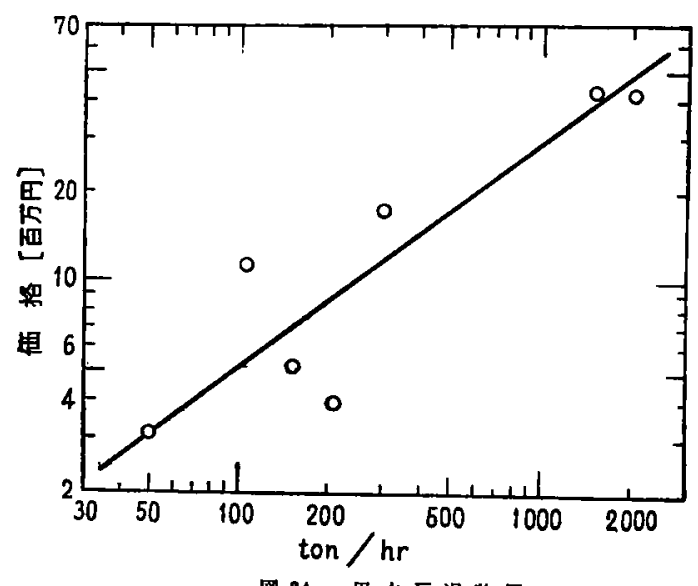

图-34用水汇遇贯

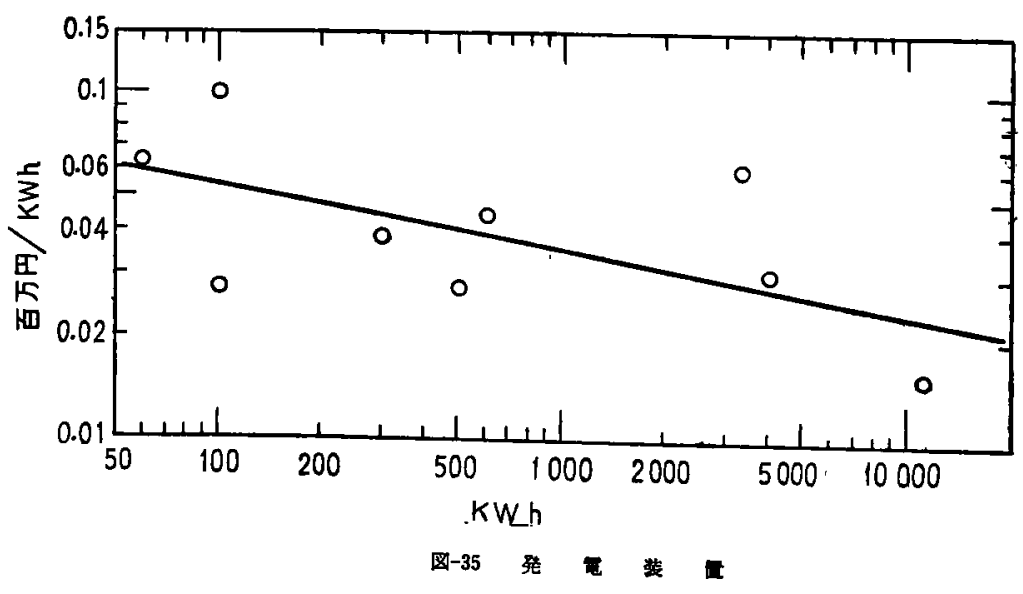

